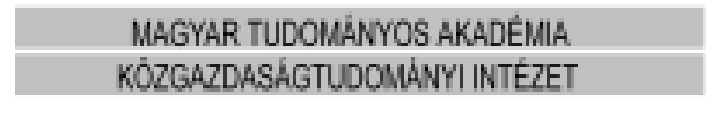

MÜHELYTANULMÁNYOK

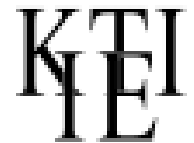

MT-DP. 2004/12
INSTITUTE OF ECONOMICS

HUNGARIAN ACADEMY OF SCIENCES

DISCUSSION PAPERS

FIRMS' PRICE MARKUPS AND RETURNS TO SCALE IN IMPERFECT MARKETS:

BULGARIA AND HUNGARY

\author{
RUMEN DOBRINSKY \\ GÁBOR KÖRÖSI \\ NIKOLAY MARKOV \\ LÁSZLÓ HALPERN
}

Institute of Economics

Hungarian Academy of Sciences

Budapest 


\title{
FIRMS' PRICE MARKUPS AND RETURNS TO SCALE IN IMPERFECT MARKETS: BULGARIA AND HUNGARY
}

\author{
RUMEN DOBRINSKY \\ GÁBOR KÖRÖSI \\ NIKOLAY MARKOV \\ LÁSZLÓ HALPERN
}


KTK/IE Discussion Papers 2004/12

Institute of Economics Hungarian Academy of Sciences

KTK/IE Discussion Papers are circulated to promote discussion and provoque comments. Any references to discussion papers should clearly state that the paper is preliminary. Materials published in this series may subject to further publication.

\section{Firms' Price Markups and Returns to Scale in Imperfect Markets: Bulgaria and Hungary}

Affiliation and contacts of authors:

Rumen DOBRINSKY: UN Economic Commission for Europe, Palais des Nations, CH-1211 Geneva, Switzerland;

e-mail: rumen.dobrinsky@unece.org

Gábor KÖRÖSI: Institute of Economics Hungarian Academy of Sciences (Budaörsi út 45. Budapest 1112 Hungary) and CEU;

e-mail: korosi@econ.core.hu

Nikolay MARKOV: Centre for Economic and Strategic Research (3 akad. Nikola Obreshkov street, apt. 1; Sofia-1113, Bulgaria);

e-mail:nmarkov@mail.ibn.bg

László HALPERN: Institute of Economics Hungarian Academy of Sciences (Budaörsi út 45. Budapest 1112 Hungary), CEPR, CEU and WDI; e-mail: halpern@econ.core.hu

This research was supported by a grant from the CERGE-EI Foundation under a program of the Global Development Network. All opinions expressed are those of the authors and have not been endorsed by CERGE-EI, or the GDN. We received valuable comments from Wendy Carlin, Evžen Kočenda, and the participants in seminars held in Prague, Budapest, Sofia and Ljubljana to earlier versions of this paper. Halpern and Körösi would like to express their gratitude to Mr. József Becsei and Mrs. Valéria Nagy Marocsek for their help in compiling the revised and extended Hungarian dataset.

HU ISSN 1785-377X

ISBN 9639588113

Published by the Institute of Economics Hungarian Academy of Sciences, Budapest, 2004.

With financial support from the Hungarian Economic Foundation 
The Publications of the Institute of Economics

BUDAPEST WORKING PAPERS ON THE LABOUR MARKET

\begin{tabular}{|c|c|c|}
\hline BWP 2003/1 & Ágnes Hárs & $\begin{array}{l}\text { Channeled East-West labour migration in the frame of bilateral } \\
\text { agreements }\end{array}$ \\
\hline BWP 2003/2 & Galasi Péter & $\begin{array}{l}\text { Munkanélküliségi indikátorok és az állásnélküliek munkaerő-piaci } \\
\text { kötődése }\end{array}$ \\
\hline BWP 2003/3 & Károly Fazekas & $\begin{array}{l}\text { Effects of foreign direct investment on the performance of local } \\
\text { labour markets - The case of Hungary }\end{array}$ \\
\hline BWP 2003/4 & Péter Galasi & Estimating wage equations for Hungarian higher-education graduates \\
\hline BWP 2003/5 & Péter Galasi & Job-training of Hungarian higher-education graduates \\
\hline BWP 2003/6 & $\begin{array}{l}\text { Gábor Kertesi and } \\
\text { János Köllö }\end{array}$ & $\begin{array}{l}\text { The Employment Effects of Nearly Doubling the Minimum Wage - } \\
\text { The Case of Hungary }\end{array}$ \\
\hline BWP 2003/7 & $\begin{array}{l}\text { Nemes-Nagy J. - } \\
\text { Németh N. }\end{array}$ & $\begin{array}{l}\text { A "hely" és a "fej". A regionális tagoltság tényezői az ezredfor- } \\
\text { duló Magyarországán }\end{array}$ \\
\hline BWP 2003/8 & Júlia Varga & $\begin{array}{l}\text { The Role of Labour Market Expectations and Admission Probabilities } \\
\text { in Students' Application Decisions on Higher Education: the case of } \\
\text { Hungary }\end{array}$ \\
\hline BWP 2004/1 & Gábor Kertesi & The Employment of the Roma - Evidence from Hungary \\
\hline BWP 2004/2 & Kézdi Gábor & $\begin{array}{l}\text { Az aktív foglalkoztatáspolitikai programok hatásvizsgálatának mód- } \\
\text { szertani kérdései }\end{array}$ \\
\hline BWP 2004/3 & Galasi Péter & $\begin{array}{l}\text { Valóban leértékelődtek a felsőfokú diplomák? A munkahelyi követel- } \\
\text { mények változása és a felsőfokú végzettségű munkavállalók } \\
\text { reallokációja Magyarországon 1994-2002 }\end{array}$ \\
\hline BWP 2004/4 & Galasi Péter & $\begin{array}{l}\text { Túlképzés, alulképzés és bérhozam a magyar munkaerőpiacon } \\
\text { 1994-2002 }\end{array}$ \\
\hline
\end{tabular}

RESEARCH IN LABOUR ECONOMICS

(Volumes based on conferences organised by KTK/IE and the Labour Science Committee HAS)

Munkaerőpiac és regionalitás az átmenet időszakában. Budapest, 1998.

Ed.: K. Fazekas

A munkaügyi kapcsolatok rendszere és a munkavállalók helyzete. Budapest, 2000.

Ed.: J.

Koltay

Oktatás és munkaerőpiaci érvényesülés. Budapest, 2001.

Ed.: A.

Semjén

A felzárkózás esélyei - Munkapiaci látlelet a felzárkózás küszöbén. Budapest, 2003. Ed.: Gy. Kővári

\section{LABOUR MARKET YEARBOOKS}

Munkaerőpiaci tükör - 2000. Budapest, 2000.

Munkaeröpiaci tükör - 2001. Budapest, 2001.

Munkaerőpiaci tükör - 2002. Budapest, 2002.

Munkaerőpiaci tükör - 2003. Budapest, 2003.

The Hungarian Labour Market - Review and Analysis, 2002. Bp., 2002

The Hungarian Labour Market - Review and Analysis, 2003. Bp., 2003

Budapest Working Papers on the Labour Market is jointly published by the Labour Research Department, Institute of Economics Hungarian Academy of Sciences and the Department of Human Resources, Budapest University of Economics and Public Administration. Copies are available from: Ms. Irén Szabó, Department of Human Resources, Budapest University of Economics, and Public Administration. H-1093 Budapest, Fővám tér 8. Phone/fax: 36-1 217-1936 E-mail: iszabo@workecon.bke.hu; Ms. Zsuzsa Sándor, Library of the Institute of Economics, H-1502 Budapest P.O. Box 262, Fax: 36-1 309-2649; E-mail: biblio@econ.core.hu. Papers can be downloaded from the homepage of the Institute of Economics: www.econ.core.hu 


\begin{tabular}{|c|c|c|}
\hline MT-DP. 2003/1 & $\begin{array}{l}\text { NACSA Beáta - SERES } \\
\text { Antal }\end{array}$ & $\begin{array}{l}\text { Az éves munkaidő-elszámolás, mint a munkaidő flexi- } \\
\text { bilizációjának egyik eszköze }\end{array}$ \\
\hline MT-DP. 2003/2 & $\begin{array}{l}\text { Giovanni PERI - Dieter } \\
\text { URBAN }\end{array}$ & $\begin{array}{l}\text { The Veblen-Gerschenkorn Effect of FDI in Mezzo- } \\
\text { giorno and East Germany }\end{array}$ \\
\hline MT-DP. 2003/3 & $\begin{array}{l}\text { Robin MASON - Ákos } \\
\text { VALENTINYI }\end{array}$ & $\begin{array}{l}\text { Independence, Heterogeneity and Uniqueness in } \\
\text { Interaction Games }\end{array}$ \\
\hline MT-DP. 2003/4 & $\begin{array}{l}\text { M.B.DEVEREUX-C. ENGEL } \\
\text {-P.E. STORGAARD }\end{array}$ & $\begin{array}{l}\text { Endogenous Exchange Rate Pass-through when } \\
\text { Nominal Prices are Set in Advance }\end{array}$ \\
\hline MT-DP. 2003/5 & Richard FRIBERG & Common Currency, Common Market? \\
\hline MT-DP. 2003/6 & $\begin{array}{l}\text { David C. PARSLEY- } \\
\text { Shang-Jin WEI }\end{array}$ & $\begin{array}{l}\text { The Micro-foundations of Big Mac Real Exchange } \\
\text { Rates }\end{array}$ \\
\hline MT-DP. 2003/7 & $\begin{array}{l}\text { J.IMBS - H. MUMTAZ - } \\
\text { M.O. RAVN - H. REY }\end{array}$ & $\begin{array}{l}\text { PPP Strikes Back: Aggregation and the Real Ex- } \\
\text { change Rate }\end{array}$ \\
\hline MT-DP. 2003/8 & $\begin{array}{l}\text { A. BURSTEIN -M. EICH- } \\
\text { ENBAUM - S. REBELO }\end{array}$ & Why is inflation so low after large devaluations? \\
\hline MT-DP. 2003/9 & MAJOROS Krisztina & $\begin{array}{l}\text { A múlt század jeles magyar közgazdásza: Varga Ist- } \\
\text { ván (1897-1962) }\end{array}$ \\
\hline MT-DP. 2003/10 & KOVÁCS Ilona & A fogyasztói árindex torzító tényezői \\
\hline MT-DP. 2003/11 & $\begin{array}{l}\text { Mária CSANÁDI-Hairong } \\
\text { LAI }\end{array}$ & $\begin{array}{l}\text { Transformation of the Chinese party-state at prefecture } \\
\text { and county level }\end{array}$ \\
\hline MT-DP. 2003/12 & Ilona KOVÁCS & Biasing Factors of the Consumer Price Index \\
\hline MT-DP. 2003/13 & Attila HAVAS & $\begin{array}{l}\text { Socio-Economic and Developmental Needs: Focus } \\
\text { of Foresight Programmes }\end{array}$ \\
\hline MT-DP. 2004/1 & Attila HAVAS & $\begin{array}{l}\text { Assessing the Impact of Framework Programmes in a } \\
\text { System in Transition }\end{array}$ \\
\hline MT-DP. 2004/2 & $\begin{array}{l}\text { Max GILLMAN-Michal } \\
\text { KEJAK }\end{array}$ & $\begin{array}{l}\text { Inflation and Balanced-Path Growth with Alternative } \\
\text { Payment Mechanisms }\end{array}$ \\
\hline MT-DP. 2004/3 & $\begin{array}{l}\text { L. AMBRUS-LAKATOS- } \\
\text { B. VILÁGI-J. VINCZE }\end{array}$ & $\begin{array}{l}\text { Deviations from interest rate parity in small open } \\
\text { economies: a quantitative-theoretical investigation }\end{array}$ \\
\hline MT-DP. 2004/4 & $\begin{array}{l}\text { HALPERN László és } \\
\text { szerzőtársai }\end{array}$ & A minimálbér költségvetési hatásai \\
\hline MT-DP. 2004/5 & FALUVÉGI Albert & $\begin{array}{l}\text { A társadalmi-gazdasági jellemzők területi alakulása } \\
\text { és várható hatásai az átmenet időszakában }\end{array}$ \\
\hline MT-DP. 2004/6 & Mária CSANÁDI & $\begin{array}{l}\text { Budget constraints in party-states nested in power rela- } \\
\text { tions: the key to different paths of transformation }\end{array}$ \\
\hline MT-DP. 2004/7 & Mária CSANÁDI & $\begin{array}{l}\text { A comparative model of party-states: the structural } \\
\text { reasons behind similarities and differences in self- } \\
\text { reproduction, reforms and transformation }\end{array}$ \\
\hline MT-DP. 2004/8 & KARSAI Judit & $\begin{array}{l}\text { Helyettesítheti-e az állam a magántőke-befektetőket? } \\
\text { Az állam szerepe a magántőke-piacon }\end{array}$ \\
\hline MT-DP. 2004/9 & Judit KARSAI & $\begin{array}{l}\text { Can the state replace private capital investors? Public } \\
\text { financing of venture capital in Hungary }\end{array}$ \\
\hline MT-DP. 2004/10 & Mária CSANÁDI & $\begin{array}{l}\text { Are specifics of the Chinese transformation suf- } \\
\text { ficient to avoid system demise? }\end{array}$ \\
\hline MT-DP. 2004/12 & $\begin{array}{l}\text { István CZAJLIK - János } \\
\text { VINCZE }\end{array}$ & $\begin{array}{l}\text { Corporate law and corporate governance. The } \\
\text { Hungarian experience }\end{array}$ \\
\hline
\end{tabular}

Copies of both series are available from Ms. Zsuzsa Sándor, Library of Institute of Economics H-1502 Budapest P.O.Box 262 Fax: (36-1) 309-2649 E-mail: biblio@econ.core.hu. Papers can be downloaded from the homepage of the Institute of Economics: www.econ.core.hu 
MT-DP. 2004/12

\title{
Firms' Price Markups and Returns to Scale IN IMPERFECT MARKETS: BULGARIA AND HUNGARY
}

BY RUMEN DOBRINSKY, GÁBOR KÖRÖSI, NIKOLAY MARKOV AND LÁSZLÓ HALPERN

\begin{abstract}
Under perfect competition and constant returns to scale, firms producing homogeneous products set their prices at their marginal costs which also equal their average costs. However, the departure from these standard assumptions has important implications with respects to the derived theoretical results and the validity of the related empirical analysis. In particular, monopolistic firms will charge a markup over their marginal costs. We show that firms' markups tend to be directly associated with the employed production technology, more specifically with their returns to scale. Accordingly, we analyze the implications for the markup ratios from the incidence of non-constant returns to scale. We present quantitative results illustrating the effect of the returns to scale index on the firms' price markups, as well as the relationship between the two indicators, on the basis of firm-level data for Bulgarian and Hungarian manufacturing firms.
\end{abstract}

JEL classification numbers: C23, D21, D24

Keywords: markup pricing, market imperfections, return to scale, Bulgaria, Hungary. 
MT-DP. 2004/12

RUMEN DOBRINSKY, KÖRÖSI GÁBOR, NIKOLAY MARKOV, HALPERN LÁSZLÓ

FELÁR ÉS VOLUMENHOZADÉK NEMTÖKÉLETES PIACOKON: BULGÁRIA ÉS MAGYARORSZÁG

\section{Összefoglalás}

Tökéletes verseny és konstans volumenhozadék esetén a homogén terméket elöállitó vállalatoknál az ár az átlagköltséggel megegyezö határköltséggel egyenlö. Ha a két szokásos feltevést megváltoztatjuk, akkor az értelemszerüen megváltoztatja az elméleti eredményeket és befolyásolja az empirikus vizsgálatokból levonható következtetéseket is. Monopolista vállalatok felárat számitanak fel a határköltségen felül. Ez a tanulmány azt mutatja be, hogy a felár szorosan összefügg az alkalmazott termelési technológiával, pontosabban a volumenhozadék nagyságával. Ennek megfelelöen azt elemezzük, hogy a nem-konstans volumenhozadék feltevése milyen hatással van a felárra. Empirikus vizsgálatokkal illusztráljuk a felár és a volumehozadék közötti kapcsolatot bolgár és magyar feldolgozóipari vállalati adatok alapján.

JEL osztályozás: C23, D21, D24

Kulcsszavak: felár, piaci tökéletlenség, volumenhozadék, Bulgária, Magyarország 


\section{NON-TECHNICAL SUMMARY}

Bulgaria and Hungary are two countries that have undergone (and are still undergoing) a fundamental economic transformation from centrally planed to market economies. Their transitional markets are immature and still marred by numerous imperfections that affect all aspects of firm performance, including the firms' price-setting mechanisms. The authors develop and test a methodology that allows to examine empirically, and on a comparative basis, the pricing behaviour of manufacturing firms in the two countries, in the environment of imperfect markets.

Under perfect competition and constant returns to scale, firms producing homogeneous products set their prices at their marginal costs which also equal their average costs. However, the departure from these standard assumptions has important implications with respects to the derived theoretical results and the validity of the related empirical analysis. In particular, firms endowed with market power will charge a markup over their marginal costs. The authors show that firms' markups tend to be directly associated with the employed production technology, more specifically with the returns to scale index, which measures the rate at which output changes as the quantities of all inputs vary. Theory usually assumes constant returns to scale which implies that output changes proportionally with inputs; however in practice this assumption does not necessarily hold. The authors develop a methodology for analyzing the implications for the markup ratios from the incidence of non-constant returns to scale in imperfect markets.

The paper addresses the following issues:

- How are the firms' price markups and returns to scale index interrelated when markets are imperfect and returns to scale are not constant?

- What are the implications of non-constant returns to scale for the measurement of firm's price markups in imperfect markets?

- How can one measure empirically price markups and non-constant returns to scale in the environment of imperfect markets?

The proposed methodology is applied on balance sheet data for Bulgarian and Hungarian manufacturing firms. On the basis of this empirical exercise, the paper presents quantitative results illustrating the effect of the returns to scale index on the firms' price markups, as well as the relationship between the two indicators. The main findings of the paper can be summarized as follows: 
- The standard procedures for estimating price markups based on the assumptions of perfect markets and constant returns to scale may lead to erroneous results, especially for a group of firms which is heterogeneous with respect to their returns to scale.

- The proposed adjustment to the price markup (based on the returns to scale index) helps to restore the theoretically important relationship between the two parameters.

- The empirical analysis suggests that small manufacturing firms in the two countries tend to operate with decreasing returns to scale and this has serious implications for their price markups.

- One of the general practical conclusions is that empirical research should devote special attention to the relationship between returns to scale and price markups. Its neglect - as practiced in most empirical works - may lead to a serious estimation bias.

The authors apply identical methodology to firm level data for two countries and come up with qualitatively similar empirical results. They consider this as further evidence of the robustness of their findings and of the conclusions that they draw from them. 


\section{INTRODUCTION}

Some of the important results of the neoclassical production theory are derived under the standard assumptions of perfect competition in product and factor markets, sometimes coupled with that of constant returns to scale. In particular, under perfect competition in efficient product and factor markets market, firms producing homogeneous products set their prices at their marginal costs which, under constant returns to scale, also equal their average costs. Put differently, under perfect competition firms adjust their output level and cost structure so that to set their marginal costs equal to the exogenous price level.

The assumptions of perfect competition and constant returns to scale - as well as the theoretical results derived in a framework that incorporates them - are often applied in empirical studies as well, including microeconomic studies based on firm-level data. However, recent theoretical advances as well as the related empirical research have shown that the departure from these standard assumptions may have important implications with respects to the derived theoretical behavioral characteristics and the validity of the conclusions based on the related empirical analysis. Relaxing some of the assumptions of perfect competition and constant returns to scale has led to various extensions of the standards neoclassical results.

Among the first papers that challenged some of the standard neoclassical assumptions was the seminal work by Hall (1988). He questioned the assumption of perfect competition on product markets, and tested the equality of prices and marginal costs (under the assumption of constant returns to scale) using longitudinal industry-level data for this purpose. His empirical results provided strong evidence against the joint hypothesis of perfect competition and constant returns to scale. He also showed that the primal Solow residual can be decomposed into two parts: a price markup and a technological change component. In another seminal paper, Roeger (1995) elaborated further Hall's approach, preserving the assumption of constant returns to scale. He established that, similarly to the primal, the dual Solow residual can also be decomposed into two such components. Moreover, he argued that the presence of market power - a violation of the conditions for perfect competition - induces a wedge between the primal and the dual residuals. Kee (2002) went one step further, deriving the form of the Solow residuals for the case of non-constant returns, showing that the latter also contributes to the formation of a price markup. He also showed that imperfect competition alone cannot explain the existence of a 
wedge between primal and dual Solow residuals in the case when factor shares remain constant.

The works of Hall and Roeger inspired a series of empirical studies. While most of these were conducted on the basis of longitudinal sectoral data (time series of aggregated sectoral data), more recently the same method has been applied to firm-level data (using either cross-sectional or pooled enterprise data), which in principle opens wider opportunities to analyse micro behaviour.

In this paper we analyze empirically the implications of resolving the assumption of constant returns to scale on the markup ratios. We show that firms' pricing behavior in imperfect markets tends to be directly associated with the characteristics of their production technology, in particular, with their returns to scale and hence efficiency. In our approach the returns to scale parameter is estimated separately, in the context of the underlying production technology. The returns to scale index is then used for correcting the value of the estimated markup ratio.

This approach is used for the comparative empirical analysis of the Bulgarian and Hungarian manufacturing firms. These two countries were undergoing a fundamental economic transformation from plan to market in the 1990's. Their markets were gradually taking shape but, for obvious reasons, they were marred by numerous imperfections during this period. Accordingly, the assumption of perfect markets is clearly not applicable for the conditions that prevailed in these economies. Moreover, our empirical results do show that in these conditions the standard assumptions of perfect competition and constant returns to scale may lead to important distortions in the empirical results concerning the firms' pricing behavior. We apply an identical methodology to the enterprise data for the two countries and derive fully comparable empirical results, which increases the robustness of our empirical findings.

\section{MARKUP PRICING IN IMPERFECT MARKETS: THEORETICAL BACK- GROUND AND EMPIRICAL MEASUREMENT}

It is a well-established result in production theory that under perfect competition in efficient product and factor markets market, firms producing homogeneous products set their prices at their marginal costs. In addition, if the production technology is characterized by constant returns to scale, and there are no dynamic effects, average costs equal marginal costs and hence the output price. These conditions do not necessarily hold in a world 
of imperfect competition: thus the incidence of a monopolist endowed with market power may result in a shift of the equilibrium point away from its would-be position under perfect competition. If the demand curve faced by a monopolist producing product $y$ is downward sloping, the equilibrium price $p_{y}$ will exceed the marginal cost $\mu$ by a markup $\theta(\theta>1)$ which depends on the price elasticity of demand $\eta$ :

$$
\theta=p_{y} / \mu=1 /(1+1 / \eta)
$$

In other words, monopolistic firms may use their market power to set prices above their marginal costs.

While price markups over marginal costs are considered to be important characteristics of firms' behaviour in imperfect markets, they are not directly observable. Apart from the theoretically justifiable expectation that $\theta>1$ (as the elasticity of demand $\eta$ for a downward sloping demand curve is negative) there are no other priors as to the values of the markups. Their actual measurement has long interested empirical economists and various approaches to their indirect estimation have been suggested in the literature. The differences in approaching the measurement issue stem both from the underlying theoretical methodology and from the specific objective of the measurement exercise (e.g. to quantify the markups charged by individual firms on individual products, or to measure the average markups of individual firms, or to estimate the average markups across specific industries).

The definitional identity (1) offers two possible straightforward approaches to the measurement of the firm's markups: one of them requires relevant data on the firm's output prices and marginal costs; the second necessitates the quantification of the price elasticity of demand faced by the firm. Roberts and Supina $(1996,2000)$ have applied the first of these approaches to analyze the price markups charged by different producers on a set of 13 homogeneous products. To do that they specify and estimate a cost function using plant level data and then construct estimates of the marginal cost that vary by plant. The individual firm-level markups can be then calculated using plant level output price data. Morrison (1992) uses a similar approach based on generalized Leontief cost and expenditure functions to analyze the markup behaviour of U.S. and Japanese firms. The second approach (based on the demand elasticity) has been explored in Justman (1987) and Shapiro (1987), among others. The main practical problem of these two approaches (and the reason why their application has been relatively limited) is that they require detailed firm-level price and cost information which, in general, is not readily available and may be difficult to obtain. 
Another strand in the empirical literature originates in the seminal paper by Hall (1988) who analyzed the implications of market power on productive efficiency, factor demand and pricing behaviour. Using a two-factor production function, Hall showed that under imperfect competition the primal Solow residual is not solely attributed to autonomous technical change, but may partly reflect monopolistic pricing behaviour. He used his derivation to estimate average industry markups using for this purpose longitudinal industry-level data. Hall's approach was tested and extended in a number of subsequent studies (Shapiro, 1987; Domowitz, Hubbard and Petersen, 1988, among others).

Roeger (1995) established that in the presence of market power (violating the conditions for perfect competition), the dual Solow residual can also be decomposed into two such components: one attributed to autonomous technical change and another one - to the markup charged by the monopolistic firm. Importantly, he derived an easily estimable equation from the emerging wedge between the primal and dual Solow residuals that can be used for direct estimation of price markups. One of the most attractive features of Roeger's approach is the fact that it is exceptionally undemanding with respect to data: thus in the case of a two-sector production function its application only requires (firm- or industry-level) nominal values of value added, labour and capital costs.

Hall's work and, especially, Roeger's result inspired a series of empirical studies. While in principle this approach is perfectly feasible for the estimation of the markups charged by individual firms, most of the related empirical studies seek to measure average industry-level markups, the main constraint apparently being the significant level of noise in the data of individual firms. In addition, most of the related empirical work has been based on longitudinal sectoral data (time series of aggregated sectoral data), rather than firm data proper. Thus Oliveira Martins, Scarpetta and Pilat (1996) and Oliveira Martins and Scarpetta (1999) estimated sectoral markup ratios on the basis of longitudinal data for the OECD economies. Several studies related variations in markup ratios to the business cycle (Bloch and Olive, 2001; Linnemann, 1999; Weiss, 2000; Wu and Zhang, 2000). In a cross-country study, Hoekman, Kee and Olarreaga (2001) analyzed the impact of import competition and domestic market regulation on the formation of industry-level markups. Kee (2002) used an extension of Roeger's approach for the case of non-constant returns to scale (both Hall and Roeger assume constant returns to scale) to compute markups for Singapore's manufacturing industries, again on the basis of longitudinal sectoral data for 1974-90. 
More recently the same method has been applied to firm-level data (using either cross-sectional or pooled enterprise data), which in principle opens wider opportunities to analyze micro behaviour. Basu and Fernald (1997) emphasize the importance of inter-sectoral heterogeneity when analyzing the relationship of markups and returns to scale, even from the macroeconomic viewpoint. This also facilitates the resolution of one rigid assumption incorporated in studies based on industry-level data, namely that the markups are either time-invariable or directly related to the business cycle. Using this type of data some studies have not only attempted to estimate markup ratios but have also tried to assess the impact of competitive pressure on their formation (Dobrinsky, Markov and Nikolov, 2001; Halpern and Körösi, 2001a; Konings, Van Cayseele and Warzynski, 2003). In a similar vein, Konings, Van Cayseele and Warzynski (2001) seek to identify whether competition policy matters in shaping the firms' pricing behavior.

Both the main theoretical results and most of the empirical studies refer to the case of a two-factor production technology with output defined as value added. However, Norrbin (1993) pointed out that defining the markup over value added may induce an upward bias in estimations. Basu and Fernald (1997) emphasize that value added can only be interpreted as an output measure under perfect competition, and its use suffers from omitted variable bias under imperfect competition. Noting this, Oliveira Martins, Scarpetta and Pilat (1996) proposed an extension of Roeger's model for a production function defined over sales and incorporating material inputs as well (but preserving the assumption of constant returns to scale). In this extension the main features remain intact while the data requirements only rise slightly to include nominal material costs.

\section{PRice MaRkUPS AND RetURNS TO SCALE}

Most empirical studies so far have neglected one specific aspect of markup pricing, namely the existing link between the markup ratio and the returns to scale index in the case of non-constant returns to scale. We illustrate this link in the following simplified theoretical setup. Assume that the production technology of a representative firm is characterized by a production function $y=f(\boldsymbol{x})$, where $\boldsymbol{x}$ is the vector of inputs. Alternatively, it can also be defined by the dual cost function $C=C(y, \boldsymbol{p})$, where $\boldsymbol{p}$ is the vector of factor prices. It is assumed that both $f$ and $C$ possess all the conventional properties that validate the duality theorems. Let the production technology be characterized by a returns to scale index $\lambda$ which 
in accordance with the theory of production duality (see, e.g. Fare and Primont, 1995) can be expressed as:

$$
\lambda=\left[\Sigma x_{i}\left(M f / M x_{i}\right)\right] / f(\boldsymbol{x})=(C / y) / \mu,
$$

where $C / y$ is the average cost of producing one unit of output and $\mu$, as before, denotes the marginal production cost $\mu=M C / M y$. From eq. (2) the marginal cost can be determined as $\mu=(C / y) / \lambda$. Substituting the latter in eq. (1) establishes a direct relationship between the markup and the returns to scale indices:

$$
\theta / \lambda=p_{y} y / C .
$$

The right-hand side of this expression is nothing else than the firm's average profit margin. Hence eq. (3) suggests that a monopolist operating a production technology characterized by a returns to scale index $\lambda$ will achieve an average profit margin which equals the markup over marginal $\operatorname{costs} \theta$ divided by the returns to scale index. From a theoretical point of view eq. (3) establishes a direct structural relationship between (the unobservable) returns to scale and markup indices and the (observable) average profit margin.

It should be pointed out that while eq. (3) is established as a structural relationship, it does not imply anything as regards the direction of causality between the two structural parameters. Besides, the non-linear nature of this relationship prevents its direct use for empirical purposes: thus one and the same average profit margin may be consistent with an infinite number of combinations of $\lambda$ and $\theta$. Hence, while this relationship sets up an issue, it offers little help in resolving the problems associated with it.

Similarly to the measurement of the price markup, the actual quantification of the returns to scale index is essentially an empirical issue. But one of the important implications of eq. (3) is that the link between these parameters is of a structural nature which should in principle be incorporated in the actual estimation procedure. It should be noted that while this qualification also applies to the estimation of the returns to scale index, this has so far been widely neglected in the related empirical literature.

The empirical literature dealing with returns to scale is very extensive (for a comprehensive overview of issues and problems see Quinzii, 1992). The mainstream approach starts with an assumption about the functional form of the underlying production technology and seeks to estimate the resultant production function (characterized by a specific returns to scale index). Alternatively, the starting point can be the dual cost function: assuming a 
functional form of the cost function and estimating it also yields the returns to scale index on the basis of the duality property (2).

The returns to scale index is present (explicitly or implicitly) in all empirical estimations of price markups. However, most of these studies do not take into account the relationships between returns to scale and markups, often assuming constant returns to scale. Only very few studies note the structural nature of the relationship between the markup and the returns to scale index which requires that the two parameters be jointly considered in a broader structural framework.

Roberts and Supina (2000) estimate a cost function that is characterized by a returns to scale factor and the latter, in turn, is implicitly present in their estimates of price markups. Among the problems associated with this approach they note that unobserved efficiency differences may lead to upward biased estimates of returns to scale and hence may cause an upward bias in the markups. Both Hall's and Roeger's models (as well as the empirical works based on these models) assume constant returns to scale. This may be a rather restrictive assumption for empirical applications while the departure from the assumption of constant returns to scale invalidates some of the theoretical results of these two models. Moreover, disregarding these implications in the case of non-constant returns to scale may involve an important estimation bias and may lead to erroneous empirical conclusions.

\section{ESTIMATION OF MARKUPS IN THE CASE OF NON-CONSTANT RETURNS TO SCALE}

As noted, theory suggests that the markup and the returns to scale index are two elements of a broader, simultaneous structural relationship. Given the existing structural link between these two parameters, the most natural approach to their estimation would be their joint estimation in a system of structural equations where, on the one hand, the returns to scale index is treated as a parameter of the production technology and, on the other hand, the relation between markup and returns to scale is specified as a structural characteristic of the system. ${ }^{1}$ Kee (2002) is among the few authors who

\footnotetext{
${ }^{1}$ In principle, it would seem appealing to use directly for this purpose the structural identity (3) which not only establishes a direct and straightforward link between the markup and the returns to scale index but also relies on easily observable firm per-
} 
address the structural nature of the relationship between returns to scale and markups. He proposes a framework for their joint simultaneous estimation using the derived log differences of the underlying production and cost functions (both of which contain the markup and the returns to scale index) by assuming a functional form for the technical progress term and by imposing cross-equation restrictions on the estimated parameters.

The main practical problem in the empirical application of Kee's approach is that it is rather data demanding: its implementation at the firm level would imply the use of firm-level price data which, as a rule, are very difficult to obtain. ${ }^{2}$ For this purpose we suggest a simplified three-step approach, through the introduction of adjustments to the price markups corresponding to constant returns to scale. Note that the firm's performance characteristic, underlying the possible measurement bias in the estimation of price markups, is the returns to scale index. Due to this, in a first step we estimate the returns to scale index for the firm, or group of firms. Due to this, in a first step we estimate the returns to scale index for the firm, or group of firms. To do that we need to define the underlying production technology (either through a production, or through a cost function); we then estimate the production (or cost) function and derive the returns to scale index as a function of the estimated parameters. In a second step we estimate a markup equation, without a prior conjecture regarding the returns to scale index. In a third step, we compute an adjusted markup ratio, by superimposing the computed returns to scale index onto the price markup. The details of this procedure are spelled out below.

For example, assume that the production technology is defined by a CobbDouglas production function:

$$
Z=A L_{L}^{\alpha} M_{M}^{\alpha} K_{K}^{\alpha},
$$

where $Z, L, M$ and $K$ stand for real sales, labor, material and capital inputs, respectively, and $A$ is the measure of productive efficiency (technical progress). As well known, the returns to scale index $\lambda=\alpha_{L}+\alpha_{M}+\alpha_{K}$, so its value will be directly derived from the estimated production function.

For the estimation of price markups we apply Roeger's approach, which for the case of a three-factor production function of the type (4) comes to the estimation of the following simple regression:

$$
v^{*}=B q^{*}+\varepsilon,
$$

formance variables. However, the specific non-linear character of this relationship precludes its direct practical use in estimations.

${ }^{2}$ Kee applies his approach at the industry level using sectoral price data. 
where

$$
\begin{aligned}
& v^{*}=d z^{*}-\alpha_{L}\left(d l^{*}\right)-\alpha_{M}\left(d m^{*}\right)-\left(1-\alpha_{L}-\alpha_{M}\right)\left(d k^{*}\right), \\
& q^{*}=d z^{*}-d k^{*}
\end{aligned}
$$

In these notations, $d$ denotes differences, lower case indicates the logarithm of the corresponding variable and asterisk $(*)$ stands for nominal values. Thus $d z^{*}$ is the logarithmic difference of nominal sales, $d l^{*}$ is the logarithmic difference of labour costs, $d k^{*}$ is the logarithmic difference of capital costs and $d m *$ is the logarithmic difference of material costs.

The estimable parameter $B$ in eq. (5) is the so-called Lerner index, which in the case of constant returns to scale is linked to the markup ratio as follows:

$$
B=1-1 / \theta
$$

Hylleberg and Jørgensen (1998) and Oliveira Martins and Scarpetta (1999) showed that in the case of non-constant returns to scale, the estimable equation (5) retains its form but the estimated parameter $B^{\prime}$ has a different interpretation:

$$
B^{\prime}=1-\lambda / \theta,
$$

where $\lambda$ is the returns to scale index.

Accordingly, our estimation procedure, which seeks to quantify the firms' markup ratios in the case of non-constant returns to scale, is organized as follows:

1) First we estimate the production function (4) for groups of firms and compute their average returns to scale index $\lambda$.

2) As a second step we estimate Roeger's equation for the case of a threefactor production function: equations (5) to (7). From eq. (8) we also compute the implied average markup ratio $\theta$ for the same group of firms for the case of constant returns to scale.

3) In a third step, from eq. (9) we compute the implied markup ratio $\theta$ for the case of non-constant returns to scale. This corresponds to the introduction of a measurement adjustment to price markup, reflecting the value of the computed returns to scale index $\lambda$ for the corresponding group of firms. 


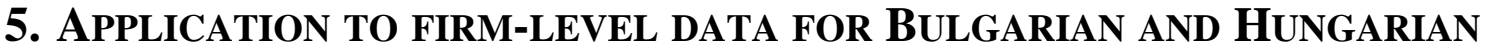 MANUFACTURING}

Most of the empirical research on the estimation of markup ratios is based on of longitudinal sectoral data, i.e. time series of aggregated performance data for manufacturing sectors. With respect to the purpose of estimating price markups, using such data is associated with a number of practical problems. The fact that sectoral level data usually only contain a limited number of observations gives rise to the technical problems related to short time series. But in addition, this type of data raises some conceptual concerns. Thus we can only obtain a single, steady-state estimate for the markup for the whole period of observation while it may be questionable whether sectoral price markups remain constant over, say, two decades. In addition, longitudinal data pose the problem of a possible interference of the business cycle with the formation of price markups. ${ }^{3}$ However, sectoral data also have one clear-cut advantage: as sectoral price data are readily available, this provides the opportunity to perform both a primal and a dual analysis.

Using firm-level data to estimate markups allows to overcome many of these difficulties and opens new analytical opportunities. In principle the approach outlined above allows to compute firm-level markups; however, as noted, due to the considerable noise which may be present in individual firm data, practically all firm-level studies so far have sought to estimate markups for groups of firms, usually belonging to the same sector or industry. In any case, one of the obvious advantages of using firm-level data for this purpose is that it becomes possible to estimate mark-ups for specific points in time, say years, using the cross-section data for the population of firms in point in time. ${ }^{4}$ Consequently, over time, this might allows to trace the impact of the cycle on the firms' pricing behaviour.

${ }^{3}$ While some studies have proposed ways of partly dealing with these issues (Oliveira Martins and Scarpetta, 1999), the problem of the direct estimation of annual markups remain.

${ }^{4}$ In principle, all theoretical results discussed above are derived under the assumption that markups remain constant within the period of differentiation (e.g., at least within two subsequent years). In practical terms, however, this is not a constraint in estimating time-varying markups. This can be done, e.g. by breaking down the observation period into subperiods for which the above assumption still holds. In the extreme, these subperiods can be pairs of subsequent years which is equivalent to estimating annual markups. 
Alternatively, average markups for a certain period of time may be estimated from panel data by introducing specific macroeconomic variables that would control for the cyclical impact. In turn, the main disadvantage of firm-level data is that usually there are no reliable sources of firm-level prices which effectively prevents a proper dual analysis.

In this study we use firm-level data for Bulgarian and Hungarian manufacturing firms. The Bulgarian dataset contains detailed enterprise balance sheets for all manufacturing firms that use the double entry accounting method and report to the National Statistical Institute (NSI), for the period 1994-2001. ${ }^{5}$ The annual reports contain the balance sheet, the profit-and-loss statement and several supplements. The total number of manufacturing firms in the dataset ranges from some 4,000 in 1994 to almost 12,000 in 2001. All firms in the Bulgarian dataset are incorporated entities but the set also covers micro firms with less than 10 employees.

The Hungarian dataset is based on balance sheet information for Hungarian firms supplemented with sectoral data. The dataset consists of the profit and loss account and balance sheet data of a sample of Hungarian manufacturing firms for the same period, and covers manufacturing firms employing at least 10 people. The sample selection is, however, biased towards the large firms. The total number of manufacturing firms in the dataset ranges from some 3000 in 1994 to 5000 in 2001. This sample includes at least $15 \%$ of all Hungarian manufacturing firms in every year (usually more than 20\%). However, the representation is much larger with respect to sales volume: the sample accounts for least $70 \%$ of all manufacturing sales in Hungary every year.

The empirical exercise reported here follows the approach outlined in the previous section. Our preferred definition of output is gross revenue (sales) and, accordingly, we assume a three-factor production function of the type (4). ${ }^{6}$ In estimating the production function we assume that the efficiency term $\mathrm{A}$ is time dependent and has the following functional form:

${ }^{5}$ In accordance with the Law on Statistics firms registered as corporate entities have to apply double entry accounting and must report their annual balance sheets to the NSI, for statistical purposes. Hence the NSI enterprise survey is in principle a full population census.

${ }^{6}$ In our own experience, similarly to the observation by Oliveira Martins, Scarpetta and Pilat (1996), the markups estimated from the definition of output as value added were often excessively high, say in the order of $50 \%$ to $100 \%$ over marginal costs 


$$
A(T)=A_{0} e^{a T} \varepsilon
$$

A series of estimations of this standard markup model was performed including both single-year and panel estimates. As could be expected, the sectoral markups based on single year estimates tended to display some time variability, which could largely be attributed to cyclical factors but also to a changing level of competitive pressure within the sectors. ${ }^{7}$ In the panel estimations we tried different estimation techniques (OLS, fixed and random effects) which produced rather similar results. As these yield average markups for the estimation period, we also included in this specification of $A(t)$ time dummies to take care of time-specific macroeconomic shocks and other time variable macroeconomic factors. Generally, the different estimation techniques produced rather similar results which could also be taken as an evidence of their robustness. In tables 1 and 2 we report some of the panel estimation results (for Bulgaria and Hungary, respectively) for the production functions and the markup equations performed at the NACE 2-digit sectoral level for the period 1995-2001, and the corresponding values for the sectoral price markups. ${ }^{8}$ We apply a completely identical methodology to the data for the two countries and thus these results are fully comparable.

As a first observation, these results suggest that while the returns to scale index in most sectors is close to one, the assumption of constant returns to scale in general cannot be taken for granted. ${ }^{9}$

(mostly likely due to the inherent estimation bias), a range that seems implausible in terms of their interpretation as a real life phenomenon.

${ }^{7}$ Single year estimates for the markups are available from the authors upon request.

${ }^{8}$ Stata and TSP were used for estimation.

${ }^{9}$ The constant returns to scale hypothesis (H0: $\alpha_{L}+\alpha_{M}+\alpha_{K}=1$ ) was rejected for most manufacturing sectors in Bulgaria, and approximately for half of the cases for Hungary. 


\section{Table 1: Separate estimation of Cobb-Douglas production functions and markup equations for Bulgarian manufacturing sectors (OLS panel estimations, 1995-2001)}

Dependent variable in production function: total revenue (net sales); estimation in logarithms of levels. Markup equation: Roeger type estimation of the Lerner index.

\begin{tabular}{|c|c|c|c|c|c|c|c|c|c|c|c|c|}
\hline \multirow{2}{*}{$\begin{array}{l}\text { NACE } \\
\text { 2-digit } \\
\text { sectors }\end{array}$} & \multicolumn{8}{|c|}{ Estimated production function } & \multicolumn{2}{|c|}{$\begin{array}{c}\text { Estimated markup } \\
\text { equation ( } \mathrm{RS}=\text { const) }\end{array}$} & \multicolumn{2}{|c|}{$\begin{array}{l}\text { Implied markup with } \\
\text { non-constant RS }\end{array}$} \\
\hline & $\begin{array}{c}\text { Const } \\
\mathrm{A}_{0}\end{array}$ & $\begin{array}{c}\text { Time } \\
T \\
\end{array}$ & $L$ & $M$ & $K$ & $\mathrm{R}^{2}$ & N obs. & $\begin{array}{c}\text { Returns to scale } \\
\lambda\end{array}$ & $\begin{array}{c}\text { Markup } \\
\theta\end{array}$ & $\mathrm{R}^{2}$ & $\begin{array}{c}\text { Markup } \\
\theta\end{array}$ & $\begin{array}{c}\% \text { measure- } \\
\text { ment bias }\end{array}$ \\
\hline 15 & $1.598 * *$ & $-0.009 * *$ & $0.119 * *$ & $0.788 * *$ & $0.067 * * *$ & 0.963 & 5874 & $0.974 * *$ & $1.306 * *$ & 0.502 & 1.272 & 2.7 \\
\hline 16 & $2.637 * *$ & -0.017 & $0.135 * *$ & $0.703 * *$ & $0.095 * * *$ & 0.962 & 149 & $0.932 * *$ & $1.337 * *$ & 0.572 & 1.247 & 7.2 \\
\hline 17 & $1.948 * *$ & $0.029 * *$ & $0.181 * *$ & $0.739 * *$ & $0.040 * * *$ & 0.979 & 945 & $0.959 * *$ & $1.252 * *$ & 0.470 & 1.201 & 4.2 \\
\hline 18 & $2.285 * *$ & $-0.013 * *$ & $0.264 * *$ & $0.625 * *$ & $0.098 * * *$ & 0.953 & 2766 & $0.987 * *$ & $1.261 * *$ & 0.481 & 1.244 & 1.4 \\
\hline 19 & $2.096 * *$ & -0.011 & $0.222 * *$ & $0.687 * *$ & $0.076 * * *$ & 0.970 & 590 & $0.986 *$ & $1.234 * *$ & 0.489 & 1.216 & 1.5 \\
\hline 20 & $1.855 * *$ & $0.022 * *$ & $0.140 * *$ & $0.751 * *$ & $0.053 * * *$ & 0.955 & 1214 & $0.944 * *$ & $1.227 * *$ & 0.401 & 1.158 & 5.9 \\
\hline 21 & $1.392 * *$ & $0.050 * *$ & $0.112 * *$ & $0.814 * *$ & $0.046 * * *$ & 0.978 & 550 & $0.973 * *$ & $1.243 * *$ & 0.462 & 1.209 & 2.8 \\
\hline 22 & $1.928 * *$ & $-0.128 * *$ & $0.148 * *$ & $0.750 * *$ & $0.075 * * *$ & 0.948 & 1336 & $0.972 * *$ & $1.252 * *$ & 0.475 & 1.218 & 2.9 \\
\hline 23 & $0.790 *$ & $-0.068 * *$ & 0.001 & $0.940 * *$ & 0.029 & 0.996 & 30 & 0.970 & $1.280 * *$ & 0.641 & 1.241 & 3.1 \\
\hline 24 & $1.615 * *$ & $-0.026 * *$ & $0.081 * *$ & $0.793 * *$ & $0.083 * * *$ & 0.980 & 1017 & $0.957 * *$ & $1.265 * *$ & 0.478 & 1.211 & 4.5 \\
\hline 25 & $1.938 * *$ & 0.006 & $0.129 * *$ & $0.737 * *$ & $0.076 * * *$ & 0.964 & 1145 & $0.942 * *$ & $1.315 * *$ & 0.488 & 1.239 & 6.1 \\
\hline 26 & $1.634 * *$ & $-0.033 * *$ & $0.108 * *$ & $0.800 * *$ & $0.055 * * *$ & 0.978 & 1004 & $0.963 * *$ & $1.218 * *$ & 0.460 & 1.173 & 3.8 \\
\hline 27 & $1.411 * *$ & $0.028 * *$ & $0.094 * *$ & $0.847 * *$ & $0.029 * *$ & 0.982 & 409 & $0.971 * *$ & $1.262 * *$ & 0.476 & 1.225 & 3.0 \\
\hline 28 & $1.899 * *$ & $-0.014 * *$ & $0.164 * *$ & $0.730 * *$ & $0.070 * * *$ & 0.950 & 2064 & $0.964 * *$ & $1.229 * *$ & 0.419 & 1.184 & 3.8 \\
\hline 29 & $1.913 * *$ & -0.003 & $0.175 * *$ & $0.740 * *$ & $0.057 * * *$ & 0.965 & 2431 & $0.971 * *$ & $1.230 * *$ & 0.460 & 1.195 & 2.9 \\
\hline 30 & $2.160 * *$ & $0.089 * *$ & $0.204 * *$ & $0.734 * *$ & 0.016 & 0.953 & 188 & $0.954 * *$ & $1.237 * *$ & 0.367 & 1.180 & 4.8 \\
\hline 31 & $1.837 * *$ & -0.009 & $0.100 * *$ & $0.762 * *$ & $0.080 * * *$ & 0.964 & 912 & $0.943 * *$ & $1.237 * *$ & 0.409 & 1.166 & 6.1 \\
\hline 32 & $2.215 * *$ & -0.029 & $0.129 * *$ & $0.676 * *$ & $0.135 * * *$ & 0.942 & 268 & $0.940 * *$ & $1.224 * *$ & 0.379 & 1.151 & 6.4 \\
\hline 33 & $2.438 * *$ & -0.015 & $0.199 * *$ & $0.702 * *$ & $0.042 * * *$ & 0.930 & 517 & $0.942 * *$ & $1.243 * *$ & 0.399 & 1.172 & 6.1 \\
\hline 34 & $1.088 * *$ & $-0.027 *$ & $0.104 * *$ & $0.818 * *$ & $0.093 * * *$ & 0.973 & 218 & 1.015 & $1.255 * *$ & 0.441 & 1.274 & -1.5 \\
\hline 35 & $1.704 * *$ & 0.007 & $0.162 * *$ & $0.776 * *$ & $0.050 * * *$ & 0.981 & 204 & 0.988 & $1.164 * *$ & 0.487 & 1.150 & 1.2 \\
\hline 36 & $1.745 * *$ & $0.021 * *$ & $0.156 * *$ & $0.754 * *$ & $0.061 * * *$ & 0.959 & 1303 & $0.970 * *$ & $1.226 * *$ & 0.464 & 1.189 & 3.1 \\
\hline 37 & $3.063 * *$ & $-0.087 *$ & 0.178 & $0.739 * *$ & 0.041 & 0.978 & 17 & 0.959 & $1.831 * *$ & 0.616 & 1.756 & 4.3 \\
\hline MAPE & & & & & & & & & & & & 3.3 \\
\hline
\end{tabular}

Notes: $*$ significant at $10 \% ; * *$ significant at $5 \% ; * * *$ significant at $1 \%$. Returns to scale: H0: $\lambda=1$; markup: H0: $\theta=1$. Time dummies (not reported in this table) were also included in the estimation of the production function. The reported $\%$ measurement bias is calculated as the $\%$ difference between the estimated and adjusted values of the price markups. MAPE - mean absolute percentage error. 


\section{Table 2: Separate estimation of Cobb-Douglas production functions and markup equations for Hungarian manufacturing sectors (OLS panel estimations, 1995-2001)}

Dependent variable in production function: total revenue (net sales); estimation in logarithms of levels; Markup equation: Roeger type estimation of the Lerner index.

\begin{tabular}{|c|c|c|c|c|c|c|c|c|c|c|c|c|}
\hline \multirow{2}{*}{$\begin{array}{l}\text { NACE } \\
\text { 2-digit } \\
\text { sectors }\end{array}$} & \multicolumn{8}{|c|}{ Estimated production function } & \multicolumn{2}{|c|}{$\begin{array}{c}\text { Estimated markup } \\
\text { equation }(\mathrm{RS}=\text { const) }\end{array}$} & \multicolumn{2}{|c|}{$\begin{array}{l}\text { Implied markup with } \\
\text { non-constant RS }\end{array}$} \\
\hline & $\begin{array}{c}\text { Const } \\
\mathrm{A}_{0}\end{array}$ & $\begin{array}{l}\text { Time } \\
\quad T\end{array}$ & $L$ & $M$ & $K$ & $\mathrm{R}^{2}$ & N obs. & $\begin{array}{c}\text { Returns to scale } \\
\lambda\end{array}$ & $\begin{array}{c}\text { Markup } \\
\theta\end{array}$ & $\mathrm{R}^{2}$ & $\begin{array}{l}\text { Markup } \\
\theta \\
\end{array}$ & $\begin{array}{l}\% \text { measure- } \\
\text { ment bias }\end{array}$ \\
\hline 15 & 0.097 & $0.003 * *$ & $0.095 * *$ & $0.846 * *$ & $0.067 * * *$ & 0.990 & 4619 & $1.008 * *$ & $1.083 * *$ & 0.120 & 1.092 & -0.8 \\
\hline 16 & $-3.987 * *$ & $0.043 * *$ & $0.181 * *$ & $0.752 * *$ & $0.129 * *$ & 1.000 & 41 & $1.063 * *$ & $1.319 * *$ & 0.630 & 1.402 & -5.9 \\
\hline 17 & $0.857 * *$ & -0.002 & $0.192 * *$ & $0.666 * *$ & $0.124 * * *$ & 0.970 & 1086 & $0.982 * *$ & $1.176 * *$ & 0.190 & 1.155 & 1.8 \\
\hline 18 & -0.131 & 0.005 & $0.335^{* *}$ & $0.574^{* *}$ & $0.127 * * *$ & 0.950 & 2042 & $1.036^{* *}$ & $1.137^{* *}$ & 0.210 & 1.178 & -3.5 \\
\hline 19 & -0.008 & 0.005 & $0.309 * *$ & $0.620 * *$ & $0.094 * * *$ & 0.950 & 818 & $1.023 * *$ & $1.117 * *$ & 0.170 & 1.143 & -2.3 \\
\hline 20 & 0.384 & 0.001 & $0.100 * *$ & $0.824 * *$ & $0.072 * * *$ & 0.980 & 1279 & 0.996 & $1.113 * *$ & 0.140 & 1.109 & 0.4 \\
\hline 21 & 0.479 & -0.001 & $0.091 * *$ & $0.867 * *$ & $0.045 * * *$ & 0.990 & 412 & 1.003 & $1.228 * *$ & 0.540 & 1.232 & -0.3 \\
\hline 22 & $0.980 * *$ & $-0.005 *$ & $0.105 * *$ & $0.829 * *$ & $0.059 * * *$ & 0.980 & 1299 & 0.993 & $1.139 * *$ & 0.330 & 1.131 & 0.7 \\
\hline 23 & $4.219 * *$ & $-0.048 * *$ & 0.208 & $1.024 * *$ & -0.126 & 1.000 & 15 & 1.107 & $1.162 * *$ & 0.880 & 1.286 & -9.6 \\
\hline 24 & 0.269 & 0.001 & $0.068 * *$ & $0.887 * *$ & $0.057 * * *$ & 0.990 & 912 & $1.012 * *$ & $1.232 * *$ & 0.370 & 1.246 & -1.1 \\
\hline 25 & 0.306 & 0.002 & $0.144 * *$ & $0.776 * *$ & $0.097 * * *$ & 0.980 & 1586 & $1.017 * *$ & $1.161 * *$ & 0.330 & 1.181 & -1.7 \\
\hline 26 & -0.135 & $0.005 *$ & $0.183 * *$ & $0.791 * *$ & $0.062 * * *$ & 0.980 & 1201 & $1.036 * *$ & $1.317 * *$ & 0.550 & 1.364 & -3.4 \\
\hline 27 & -0.278 & $0.008 * *$ & $0.114 * *$ & $0.826 * *$ & $0.051 * * *$ & 0.990 & 497 & $0.991 *$ & $1.112 * *$ & 0.240 & 1.102 & 0.9 \\
\hline 28 & $-0.449 * *$ & $0.010 * *$ & $0.162 * *$ & $0.772 * *$ & $0.071 * * *$ & 0.970 & 3469 & 1.005 & $1.177 * *$ & 0.310 & 1.182 & -0.4 \\
\hline 29 & $0.633 * *$ & 0.000 & $0.141 * *$ & $0.783 * *$ & $0.063 * * *$ & 0.970 & 2580 & $0.987 * *$ & $1.141 * *$ & 0.290 & 1.126 & 1.3 \\
\hline 30 & -0.284 & 0.011 & $0.102 * *$ & $0.790 * *$ & $0.109 * * *$ & 0.990 & 117 & 1.001 & $1.336 * *$ & 0.340 & 1.337 & -0.1 \\
\hline 31 & $-0.748 * *$ & $0.015 * *$ & $0.204 * *$ & $0.673 * *$ & $0.119 * * *$ & 0.980 & 1008 & 0.997 & $1.221 * *$ & 0.320 & 1.217 & 0.3 \\
\hline 32 & 0.397 & 0.002 & $0.219 * *$ & $0.760 * *$ & $0.056 * * *$ & 0.980 & 556 & $1.035 * *$ & $1.234 * *$ & 0.220 & 1.277 & -3.4 \\
\hline 33 & $1.438 * *$ & $-0.008 *$ & $0.166 * *$ & $0.775 * *$ & $0.056 * * *$ & 0.970 & 692 & 0.997 & $1.222 * *$ & 0.340 & 1.218 & 0.3 \\
\hline 34 & 0.419 & 0.001 & $0.147 * *$ & $0.755 * *$ & $0.120 * * *$ & 0.990 & 580 & $1.022 * *$ & $1.168 * *$ & 0.270 & 1.193 & -2.1 \\
\hline 35 & 0.222 & 0.003 & $0.172 * *$ & $0.769 * *$ & $0.063 * * *$ & 0.990 & 161 & 1.003 & $1.130 * *$ & 0.350 & 1.133 & -0.3 \\
\hline 36 & -0.074 & 0.005 & $0.186 * *$ & $0.766 * *$ & $0.065 * * *$ & 0.970 & 1230 & $1.017 * *$ & $1.145 * *$ & 0.220 & 1.165 & -1.7 \\
\hline 37 & -0.203 & 0.006 & $0.102 * *$ & $0.877 * *$ & 0.018 & 0.990 & 83 & 0.997 & $1.033 * *$ & 0.220 & 1.030 & 0.3 \\
\hline MAPE & & & & & & & & & & & & 1.9 \\
\hline
\end{tabular}

Notes:* significant at $10 \%$;* significant at $5 \%$; $* *$ significant at $1 \%$. Returns to scale: H0: $\lambda=1$; markup: H0: $\theta=1$. Time dummies (not reported in this table) were also included in the estimation of the production function. The reported \% measurement bias is calculated as the $\%$ difference between the estimated and adjusted values of the price markups. MAPE - mean absolute percentage error. 
In the middle panels of Tables 1 and 2 we present the computed sectoral markup ratios under the assumption of constant returns to scale (equation (8)). In the right-hand panel (the last two columns of the tables) we show the implied markup ratios in the case when we ease the assumption of constant returns to scale as well as the percentage difference between the two estimates of the price markup (equation (9)) which is in fact the measurement bias induced by the assumption of constant returns to scale. Generally, the difference (measurement bias) is not very large (MAPE of $3.3 \%$ in the case of Bulgaria and $1.9 \%$ in Hungary). These results are in line with the simulation results in Hylleberg and Jørgensen (1998).

At a first glance, the bias introduced by the assumption of constant returns to scale may appear as minor (within the acceptable margin of error in econometric estimation). However, one problem in this exercise is that we in fact assume that firms in each NACE 2-digit sector are characterized by the same returns to scale index. This in itself may be a too rigid assumption, potentially introducing its own estimation bias. To check this, we performed another series of estimations which seek to reduce this distorting effect.

In principle, under the assumption of perfect markets, firms operating in the same market should employ identical production technologies (hence identical returns to scale) and should be characterized by identical levels of productive efficiency as competitive pressure will drive out of the market less efficient firms. However, the deviation from the assumption of perfect market implies a possible heterogeneity in production technologies and, respectively, varying returns to scale across the same markets. However, as noted, the identification of the returns to scale index is essentially an empirical issue and there are no clear priors as to the classification of firms into groups featuring the same (or at least similar) returns to scale.

We have attempted several possible breakdowns of the firms in the samples for the two countries, and the one that did reveal differences in the returns to scale index was the breakdown by size. In tables 3 and 4 we present a selection of some of the main results (for Bulgaria and Hungary, respectively) for three size categories of firms: 1) "small firms" (firms with less than 20 employees); 2) "medium-sized firms" (firms with more than 20 
but less than 200 employees) and 3) "large firms" (firms with more than 200 employees). ${ }^{10}$

\section{Table 3: Returns to scale and price markups (estimated and corrected) for Bulgarian manufacturing firms grouped by size}

\begin{tabular}{|c|c|c|c|c|c|c|c|c|c|c|c|c|}
\hline \multirow[b]{2}{*}{$\begin{array}{l}\text { NACE } \\
\text { 2-digit } \\
\text { sectors }\end{array}$} & \multicolumn{4}{|c|}{$\begin{array}{l}\text { Firms with less than } \\
20 \text { employees }\end{array}$} & \multicolumn{4}{|c|}{$\begin{array}{l}\text { Firms with more than } 20 \text { but } \\
\text { less than } 200 \text { employees }\end{array}$} & \multicolumn{4}{|c|}{$\begin{array}{l}\text { Firms with more than } \\
200 \text { employees }\end{array}$} \\
\hline & $\begin{array}{c}\text { Returns } \\
\text { to scale } \\
\text { (RS) }\end{array}$ & $\begin{array}{c}\text { Esti- } \\
\text { mated } \\
\text { markup }\end{array}$ & $\begin{array}{c}\text { Markup } \\
\text { ad- } \\
\text { justed } \\
\text { for RS }\end{array}$ & $\begin{array}{c}\% \text { meas- } \\
\text { ure- } \\
\text { ment } \\
\text { bias }\end{array}$ & $\begin{array}{c}\text { Returns } \\
\text { to scale } \\
\text { (RS) }\end{array}$ & $\begin{array}{c}\text { Esti- } \\
\text { mated } \\
\text { markup }\end{array}$ & $\begin{array}{c}\text { Markup } \\
\text { ad- } \\
\text { justed } \\
\text { for RS }\end{array}$ & $\begin{array}{c}\% \text { meas- } \\
\text { ure- } \\
\text { ment } \\
\text { bias }\end{array}$ & $\begin{array}{c}\text { Returns } \\
\text { to scale } \\
\text { (RS) }\end{array}$ & $\begin{array}{c}\text { Esti- } \\
\text { mated } \\
\text { markup }\end{array}$ & $\begin{array}{c}\text { Markup } \\
\text { ad- } \\
\text { justed } \\
\text { for RS }\end{array}$ & $\begin{array}{c}\% \text { meas } \\
\text { ure- } \\
\text { ment } \\
\text { bias }\end{array}$ \\
\hline 15 & & 1.359 & & & & & & & & & & 1.2 \\
\hline 16 & & & & & 1.008 & & & & 0.899 & & & 11.2 \\
\hline 17 & 827 & 1.407 & & & & & & & 0.980 & & & \\
\hline 18 & .889 & 1.410 & 54 & 12.4 & 1.032 & & & & 1.082 & & & -7.6 \\
\hline 19 & 0.886 & 1.378 & 1.221 & 12.8 & 1.049 & & & -4.7 & 1.014 & & & -1.4 \\
\hline 20 & & & & & & & & 1.9 & 0.995 & & & 0.5 \\
\hline 21 & 0.894 & 1.281 & 1.146 & 11.8 & 0.981 & & & 1.9 & 0.994 & & & 0.6 \\
\hline 22 & 0.878 & 1.268 & 1.113 & & 1.037 & & & & 0.982 & 19 & & 1.8 \\
\hline 24 & 0.862 & 1.361 & 1.173 & 16.0 & 0.946 & 1.158 & 1.096 & 5.7 & 1.037 & 1.235 & 281 & -3.6 \\
\hline 25 & 0.835 & 1.378 & & 19.7 & 1.014 & & & & 0.993 & & & 0.7 \\
\hline 26 & 0.850 & & & & & & & & 0.991 & & & 0.9 \\
\hline 27 & 0.869 & 1.333 & 1.159 & 15.1 & 0.886 & 1.255 & 1.112 & 12.9 & 1.013 & 1.105 & 1.119 & -1.3 \\
\hline 28 & 0.879 & 1.262 & 1.109 & 13.8 & 1.002 & 1.177 & & $\begin{array}{l}-0.2 \\
\end{array}$ & 1.110 & 1.194 & 1.326 & -9.9 \\
\hline 29 & 0.900 & 1.284 & & & 1.013 & & & & 1.059 & & 1.225 & -5.6 \\
\hline 30 & 0.949 & 1.338 & 1.270 & 5.3 & 1.024 & 1.125 & 1.152 & -2.4 & 1.028 & 1.088 & 1.119 & -2.7 \\
\hline 31 & 0.841 & 1.315 & & 18.9 & 1.014 & & & -1.4 & 0.971 & 1.161 & 128 & 2.9 \\
\hline 32 & 0.920 & 1.242 & & 8.7 & 0.927 & & & 7.9 & 0.904 & & & 10.6 \\
\hline 33 & 0.935 & 1.305 & 1.221 & 6.9 & 0.892 & 1.125 & 1.003 & 12.2 & 0.974 & 1.108 & 1.080 & 2.7 \\
\hline 34 & 0.881 & 1.279 & 1.127 & 13.5 & 0.905 & 1.255 & 1.136 & 10.5 & 1.026 & 1.155 & 1.185 & -2.6 \\
\hline 35 & 1.002 & 1.207 & 1.209 & -0.2 & 1.171 & 1.130 & 1.323 & -14.6 & 0.987 & 1.123 & 1.108 & 1.3 \\
\hline 36 & 0.891 & 1.289 & 1.149 & 12.2 & 1.008 & 1.172 & 1.182 & -0.8 & 0.972 & 1.160 & 1.127 & 2.9 \\
\hline MAPE & & & & \begin{tabular}{|l|}
13.3 \\
\end{tabular} & & & & 4.3 & & & & 3.5 \\
\hline
\end{tabular}

Notes: The reported \% measurement bias is calculated as the \% difference between the estimated and adjusted values of the price markups. MAPE - mean absolute percentage error.

\footnotetext{
${ }^{10}$ The full estimation results by size categories are available from the authors upon request.
} 


\section{Table 4: Returns to scale and price markups (estimated and corrected) for Hungarian manufacturing firms grouped by size}

\begin{tabular}{|c|c|c|c|c|c|c|c|c|c|c|c|c|}
\hline \multirow[b]{2}{*}{$\begin{array}{l}\text { NACE } \\
\text { 2-digit } \\
\text { sectors }\end{array}$} & \multicolumn{4}{|c|}{$\begin{array}{l}\text { Firms with less than } \\
20 \text { employees }\end{array}$} & \multicolumn{4}{|c|}{$\begin{array}{l}\text { Firms with more than } 20 \text { but } \\
\text { less than } 200 \text { employees }\end{array}$} & \multicolumn{4}{|c|}{$\begin{array}{l}\text { Firms with more than } \\
200 \text { employees }\end{array}$} \\
\hline & $\begin{array}{c}\text { Returns } \\
\text { to scale } \\
\text { (RS) }\end{array}$ & $\begin{array}{c}\text { Esti- } \\
\text { mated } \\
\text { markup }\end{array}$ & \begin{tabular}{|c} 
Markup \\
ad- \\
justed \\
for RS
\end{tabular} & $\begin{array}{c}\% \text { meas- } \\
\text { ure- } \\
\text { ment } \\
\text { bias }\end{array}$ & $\begin{array}{c}\text { Returns } \\
\text { to scale } \\
\text { (RS) }\end{array}$ & $\begin{array}{c}\text { Esti- } \\
\text { mated } \\
\text { markup }\end{array}$ & $\begin{array}{c}\text { Markup } \\
\text { ad- } \\
\text { justed } \\
\text { for RS }\end{array}$ & $\begin{array}{c}\% \text { meas- } \\
\text { ure- } \\
\text { ment } \\
\text { bias }\end{array}$ & $\begin{array}{l}\text { Returns } \\
\text { to scale } \\
\text { (RS) }\end{array}$ & $\begin{array}{c}\text { Esti- } \\
\text { mated } \\
\text { markup }\end{array}$ & $\begin{array}{c}\text { Markup } \\
\text { ad- } \\
\text { justed } \\
\text { for RS }\end{array}$ & $\mid \begin{array}{c}\% \text { meas } \\
\text { ure- } \\
\text { ment } \\
\text { bias }\end{array}$ \\
\hline 15 & 0.955 & 1.094 & 1.045 & 4.7 & 1.019 & 1.081 & 1.102 & -1.9 & 0.969 & 1.094 & 1.061 & 3.1 \\
\hline 16 & & & & & 1.005 & 1.255 & 1.261 & -0.5 & 1.262 & 1.277 & 1.610 & -20.7 \\
\hline 17 & 0.877 & 1.597 & 1.401 & 14.0 & 1.009 & 1.152 & 1.162 & \begin{tabular}{|c|}
-0.9 \\
\end{tabular} & 0.905 & 1.063 & 0.962 & 10.5 \\
\hline 18 & 1.010 & 1.128 & 1.139 & -1.0 & 1.073 & 1.135 & 1.219 & -6.9 & 0.994 & 1.127 & 1.120 & 0.6 \\
\hline 19 & 0.885 & 1.268 & 1.121 & 13.1 & 1.101 & 1.119 & 1.233 & -9.2 & 1.008 & 1.146 & 1.155 & -0.8 \\
\hline 20 & 0.913 & 1.060 & 0.968 & 9.5 & 1.029 & 1.105 & 1.137 & -2.8 & 0.903 & 1.137 & 1.027 & 10.7 \\
\hline 21 & 0.966 & 1.165 & 1.126 & 3.5 & 1.031 & 1.219 & 1.256 & -2.9 & 1.020 & 1.292 & 1.318 & -2.0 \\
\hline 22 & 1.019 & 1.167 & 1.189 & -1.9 & 0.962 & 1.127 & 1.084 & 4.0 & 0.942 & 1.119 & 1.054 & 6.2 \\
\hline 24 & 0.970 & 1.171 & 1.136 & 3.1 & 1.010 & 1.170 & 1.182 & -1.0 & 1.026 & 1.059 & 1.086 & -2.5 \\
\hline 25 & 1.002 & 1.080 & 1.082 & -0.2 & 1.027 & 1.184 & 1.216 & -2.6 & 0.941 & 1.122 & 1.056 & 6.3 \\
\hline 26 & 1.007 & 1.133 & 1.140 & -0.6 & 1.044 & 1.250 & 1.305 & -4.2 & 1.048 & 1.404 & 1.472 & -4.6 \\
\hline 27 & 1.037 & 1.186 & 1.230 & \begin{tabular}{|l|}
-3.6 \\
\end{tabular} & 0.989 & 1.159 & 1.146 & 1.1 & 0.980 & 1.098 & 1.076 & 2.0 \\
\hline 28 & 0.951 & 1.186 & 1.128 & 5.1 & 1.009 & 1.167 & 1.178 & -0.9 & 0.938 & 1.339 & 1.256 & 6.6 \\
\hline 29 & 0.986 & 1.154 & 1.138 & 1.4 & 0.998 & 1.167 & 1.164 & 0.3 & 0.968 & 1.124 & 1.088 & 3.3 \\
\hline 30 & 0.766 & 1.211 & 0.928 & 30.5 & 1.030 & 1.123 & 1.157 & -2.9 & & & & \\
\hline 31 & 1.037 & 1.267 & 1.314 & -3.6 & 0.972 & 1.206 & 1.171 & 3.0 & 1.032 & 1.266 & 1.307 & -3.1 \\
\hline 32 & 1.019 & 1.170 & 1.192 & -1.8 & 1.053 & 1.269 & 1.336 & $\begin{array}{l}-5.0 \\
\end{array}$ & 1.018 & 1.390 & 1.416 & -1.8 \\
\hline 33 & 0.944 & 1.223 & 1.154 & 6.0 & 1.025 & 1.226 & 1.257 & -2.5 & 0.825 & 1.191 & 0.983 & 21.2 \\
\hline 34 & 1.016 & 1.221 & 1.241 & $\begin{array}{l}-1.6 \\
\end{array}$ & 1.046 & 1.256 & 1.315 & -4.5 & 0.958 & 1.180 & 1.130 & 4.4 \\
\hline 35 & 0.790 & 0.954 & 0.754 & 26.5 & 0.915 & 1.128 & 1.033 & 9.2 & 1.088 & 1.101 & 1.197 & -8.0 \\
\hline 36 & 0.971 & 1.085 & 1.054 & 2.9 & 1.054 & 1.176 & 1.239 & -5.1 & 0.960 & 1.097 & 1.053 & 4.2 \\
\hline 37 & 0.862 & 1.052 & 0.907 & 16.0 & 1.018 & 1.027 & 1.046 & -1.8 & & & & \\
\hline MAPE & & & & 7.2 & & & & 3.3 & & & & 6.1 \\
\hline
\end{tabular}

Notes: The reported \% measurement bias is calculated as the \% difference between the estimated and adjusted values of the price markups. MAPE - mean absolute percentage error.

One of the important empirical outcomes of this exercise is the finding that small firms in many manufacturing sectors on average tend to display 
decreasing returns to scale. ${ }^{11}$ This is especially pronounced in the case of Bulgaria where the sample includes a considerable number of small-sized firms in all manufacturing sectors (basically the full population of incorporated small firms). The same finding can also be traced in Hungary but to a smaller degree. This may be due to the fact that the Hungarian dataset excludes micro firms (those with less than 10 employees), which sometimes also leads to lower sample sizes. However, it may just be the consequence of faster Hungarian transition: Halpern and Körösi (2001b) found that small firms were characterised by strongly decreasing returns prior 1995 in Hungary, but it approached the constant returns to scale regime afterwards. In fact, returns to scales are higher for the Hungarian firms in the majority of sectors for all categories. That most probably corresponds to the much more substantial efficiency improvements of the Hungarian manufacturing sector: manufacturing output grew by close to $20 \%$ annually in this period.

On the other hand, both medium-sized and large manufacturing firms (both in Bulgaria and in Hungary) were in most cases found to operate at close to constant returns to scale. ${ }^{12}$ It is thus the category of small firms for which the non-adjusted estimation of the price markups will contain the biggest, upward measurement bias. To illustrate this we present in tables 3 and 4 both the markup ratios computed with constant returns to scale, and those with the adjustment for non-constant returns, as well as the corresponding percentage difference (measurement bias). Indeed, in the case of Bulgarian small firms this difference is in most cases between 10 and 20\%, which can already be considered as a large measurement bias. In the case of Hungary the difference is somewhat smaller but there are a few cases of double-digit measurement bias. But also among the size categories of medium-sized and large firms, firms in some manufacturing sectors were found to operate with returns to scale deviating substantially from 1, which also leads to a notable measurement bias in the corresponding price markups.

Bulgarian sectoral markups are close to 10-percentage point higher on average than the Hungarian ones, although with substantial variations. This difference, however, disappears when comparing markup estimates for the

${ }^{11}$ This finding is in line with the empirical literature on small firms which generally finds that such firms tend to operate with decreasing returns to scale.

12 Interestingly, as can be seen on tables 3 and 4, medium-sized firms both in Bulgaria and in Hungary on average display slightly higher returns to scale than large firms. 
separate size categories. This indicates the importance of properly handling firm heterogeneity in empirical analysis.

Another related - and relevant - question that could be addressed in the context of this exercise is whether there exists any relation between the estimated values of the average sectoral returns to scale and markup ratios. The structural relationship between these two parameters at the firm level (equation (3)) suggests that they are related to each other through the firm's average profitability ratio. However, profitability varies across firms and thus the structural equation does not establish a direct relationship between returns to scale and markup ratios at the firm level. However, what we have estimated are the sectoral returns to scale and markup ratios which are averaged not only across the corresponding groups of firms but also over time. In fact, in the presence of arbitrage, average sectoral profitability over time will tend to equalize across sectors. Hence, if profitability in eq. (3) is kept constant, then the estimated values of the returns to scale and markup ratios should be linearly related.

To test this we have plotted on the three panels of Figures 1 and 2 the scatter diagrams illustrating the relationship between sectoral returns to scale and markups for the three size categories of firms (for Bulgaria and Hungary, respectively). These diagrams hint at the existence of a strong positive correlation between returns to scale index and price markups. Indeed, in the case of Bulgaria, the coefficient of correlation between returns to scale index and price markup ratio for small firms is 0.56 , for medium-sized firms 0.74 and for large firms 0.67. In Hungary, the corresponding coefficients of correlation are $0.64,0.64$ and 0.80 . Notably, the relation is present for all categories of firms and in all these cases its shape is similar (for obvious reasons, the scatter diagram for small firms is shifted to the left). This is in line with the theoretical prior and also confirms the theoretical prediction of Basu and Fernald (1997) that returns to scale and price markups should be strongly (positively) correlated. The importance of correcting markup estimates by the returns to scale factor is highlighted by the fact that this positive relationship is not observable for the unadjusted markups: the correlation coefficients are close to zero for Hungary for all size categories, and they are negative for Bulgaria in all cases. Even though the differences between adjusted and non-adjusted markups seem to be small in many cases, the proposed correction restores the theoretically important relationship. 
Figure 1: Returns to scale and markup ratios in Bulgarian manufacturing by NACE-2 digit sectors and size of firms

A. Firms with less than 20 employees

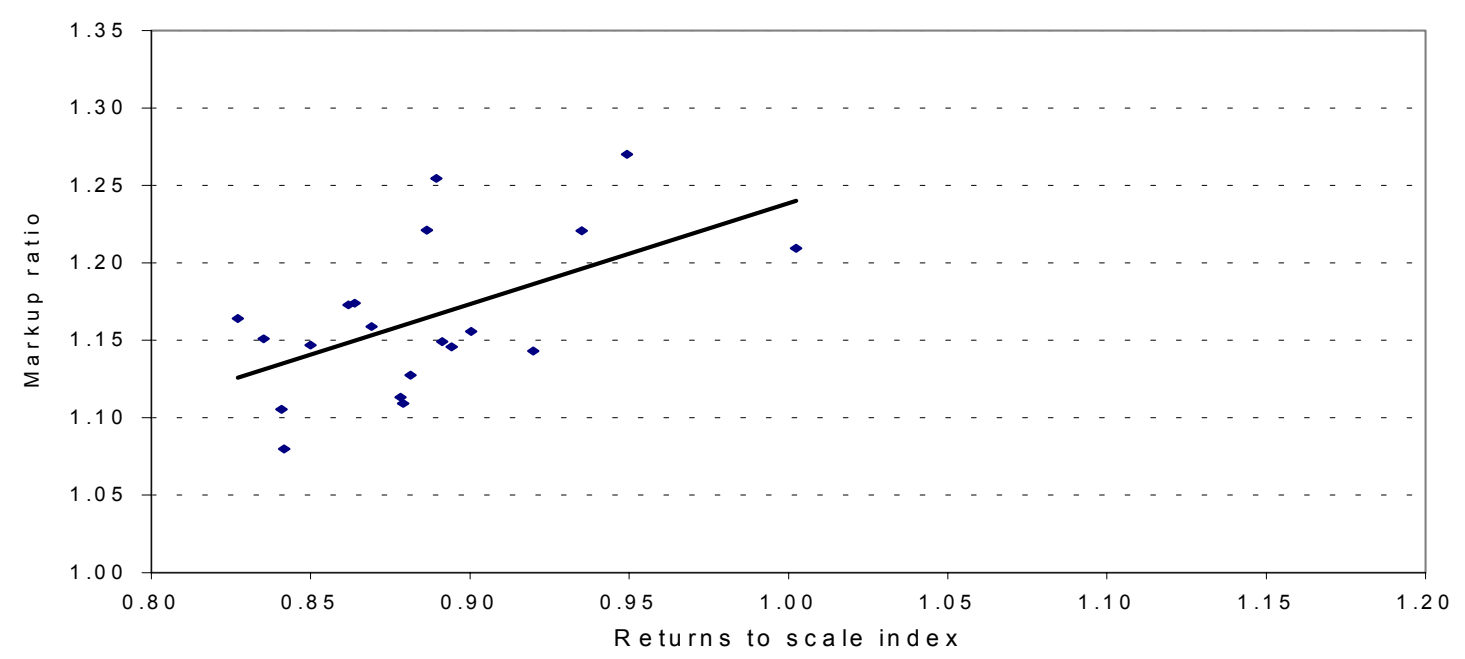

B. Firms with more than 20 but less than 200 employees

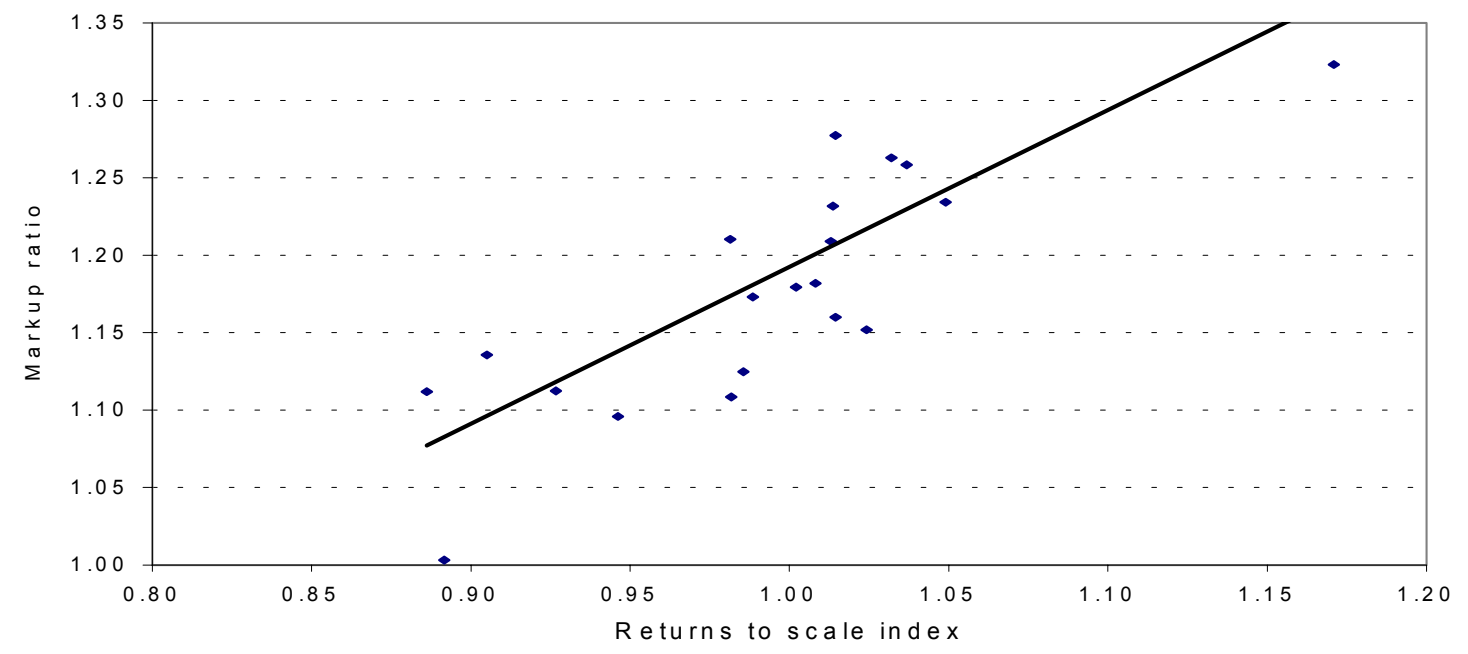

C. Firms with more 200 employees

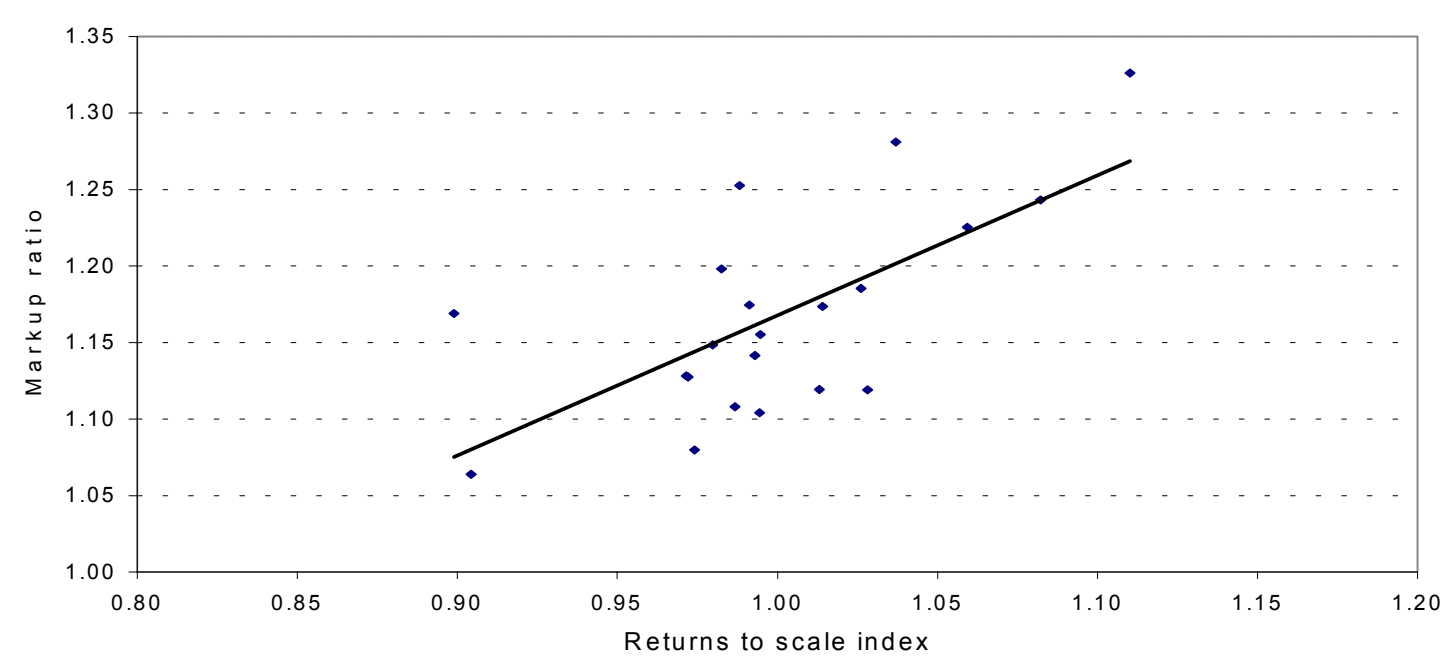


Figure 2: Returns to scale and markup ratios in Hungarian manufacturing by NACE-2 digit sectors and size of firms

A. Firms with less than 20 employees

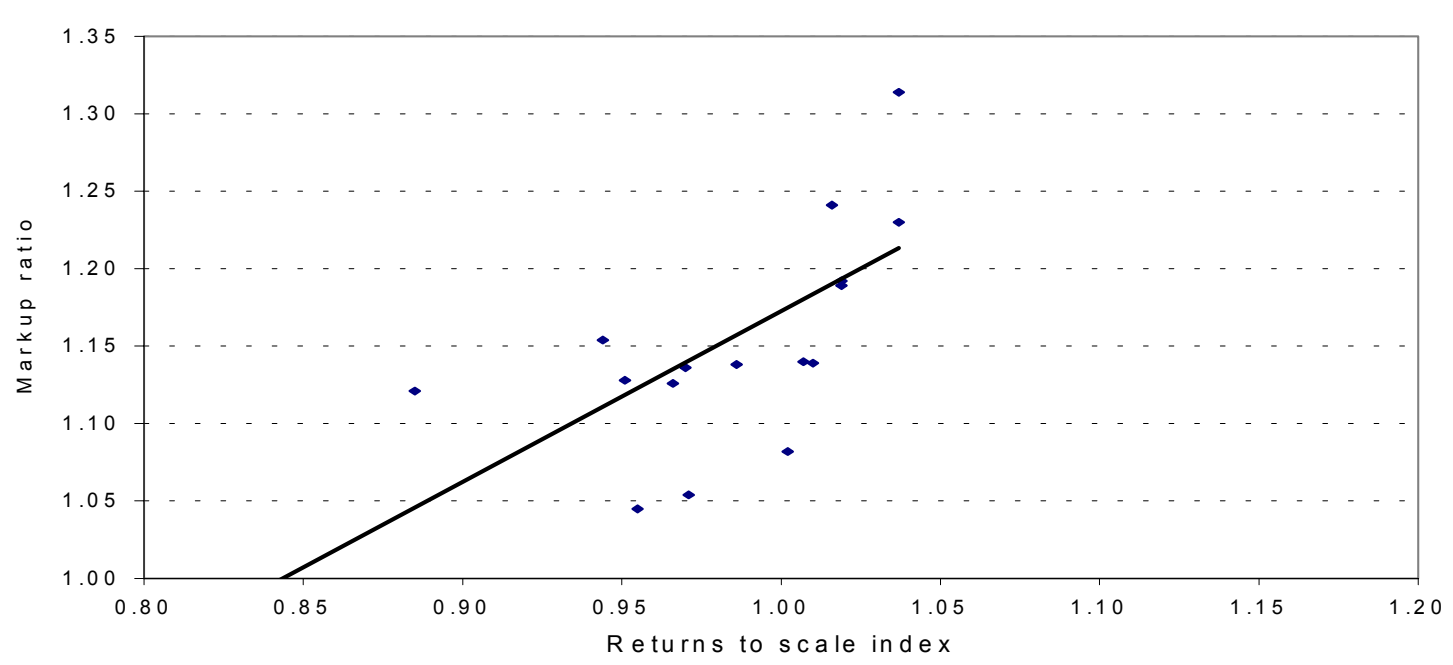

B. Firms with more than 20 but less than 200 employees

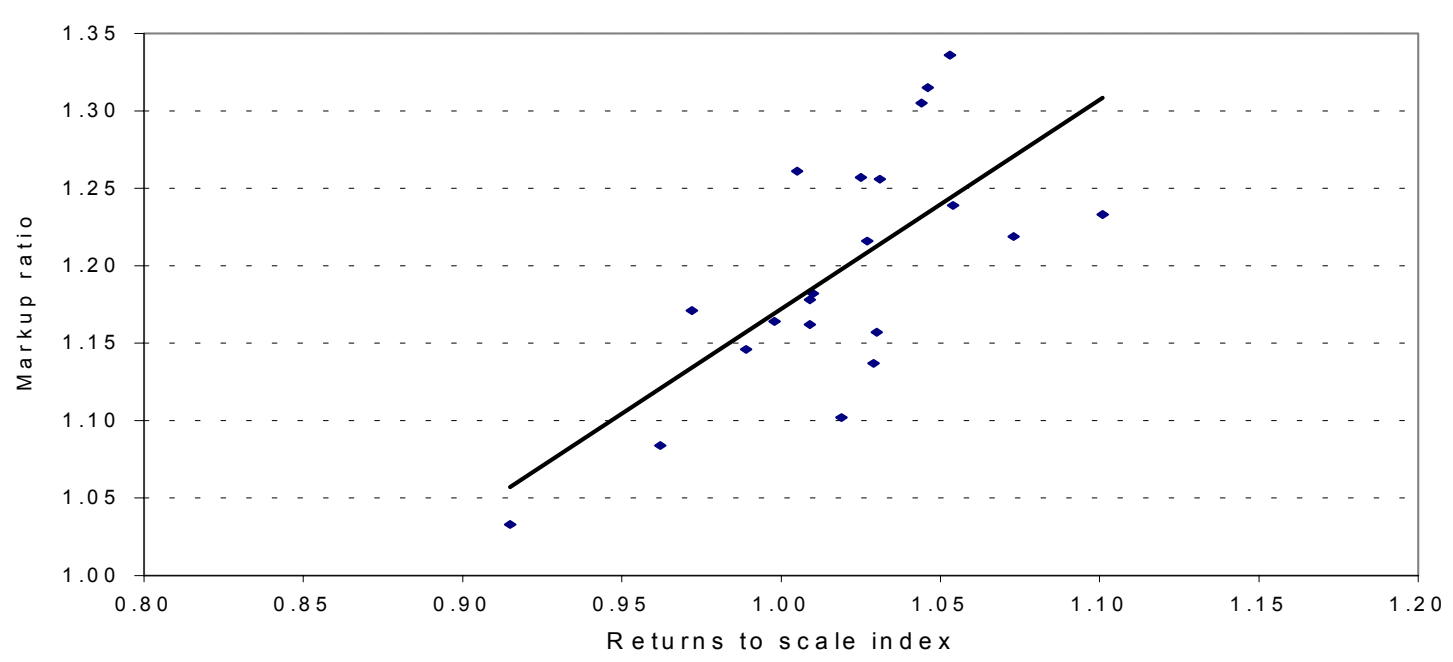

C. Firms with more 200 employees

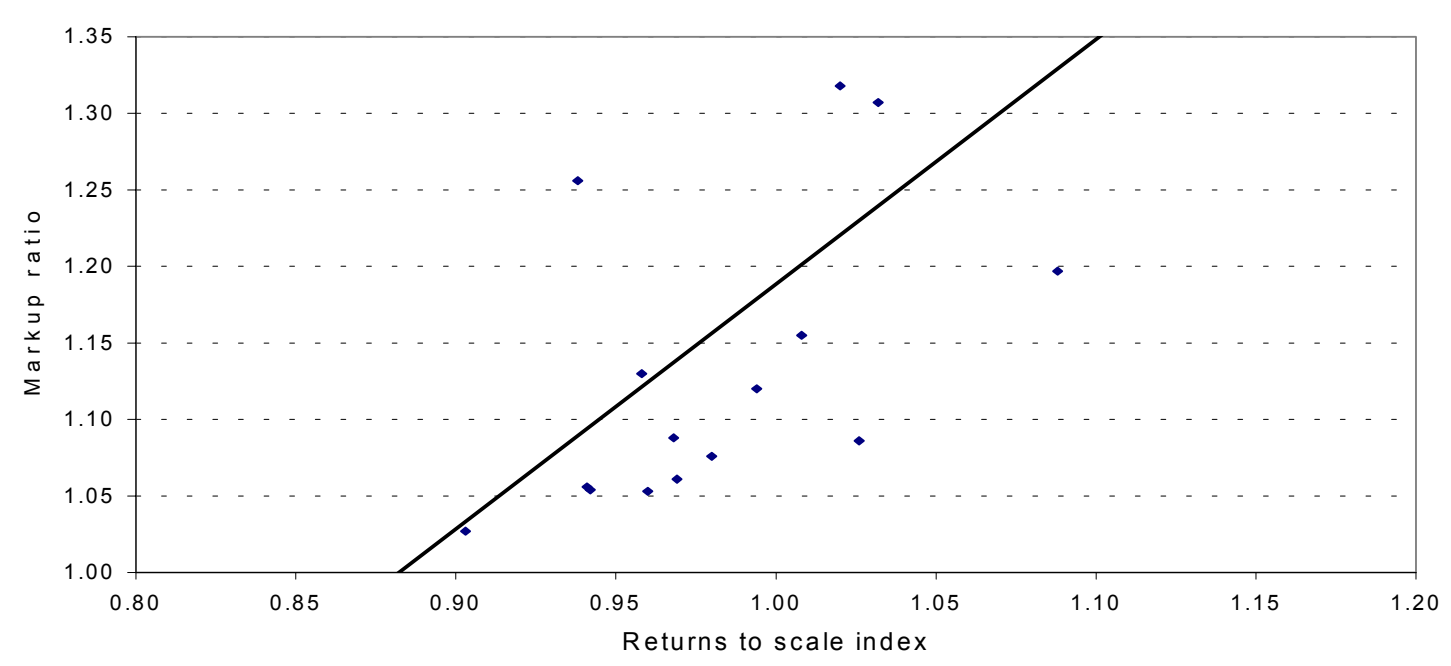




\section{CONCluding REMARKS}

In this paper we discuss the relationship between price markups and returns to scale in imperfect markets and the implications of this relationship for the empirical estimation of these two parameters. We propose an approach for the empirical estimation of markup ratios with an adjustment for the case of nonconstant returns to scale. The idea of this approach is first to determine the average returns to scale index for a group of firms and then to use it in order to make an adjustment to the markup ratio for the same category of firms.

The suggested approach has been tested on balance sheet data for Bulgarian and Hungarian manufacturing firms. The use of identical methodology allows us to produce fully comparable results for the two countries. Using the suggested approach, we estimate for both countries sectoral markups and returns to scale indexes with and without the adjustment for non-constant returns.

We show that the application of standard procedures for estimating average price markups based on the assumption of constant returns to scale may lead to a serious bias. This may occur if the markup is estimated for a group of firms which is heterogeneous with respect to the actual returns to scale index at which different firms operate. In particular, we find in our empirical analysis that small manufacturing firms tend to operate with decreasing returns to scale. Ignoring this fact in the estimation of their markup ratios will result in a considerable upward bias in their estimated price markups. Moreover, this will also be the case when markups are estimated for groups of firms which lump together small and larger firms. One of the general practical conclusions of our exercise is that empirical research in this area should devote special attention to the relationship between returns to scale and price markups and the related implications.

We also analyse empirically the relationship between returns to scale and their price markups. We find the existence of a strong positive correlation between the estimated sectoral returns to scale and price markups indices, which is in line with the theoretical prior. The importance of correcting markup estimates by the returns to scale factor is highlighted by the fact that this positive relationship is not observable for the unadjusted markups. The proposed correction in the markups helps to restore this theoretically important relationship.

Finally we note that we apply identical methodology to firm level data for two countries and come up with qualitatively similar empirical results. We consider this as further evidence of the robustness of the results and of the conclusions that we draw from them. 


\section{REFERENCES}

Basu, Susanto, Fernald, John G. (1997): Returns to scale in US production: Estimates and implications. Journal of Political Economy 105, 249-283.

Bloch, Harry, Olive, Michael (2001): Pricing over the cycle. Review of Industrial Organization 19, 99-108.

Dobrinsky, Rumen, Markov, Nikolay, Nikolov, Boyko (2001): Markup pricing in Bulgarian manufacturing, Working Paper No. 389. William Davidson Institute at the University of Michigan Business School, Ann Arbor, Michigan.

Domowitz, Ian, Hubbard, R. Glenn, Petersen, Bruce C. (1988): Market structure and cyclical fluctuations in U.S. manufacturing. Review of Economics and Statistics, 70, 55-66.

Fare, Rolf, Primont, Daniel (1995): Multi-Output Production and Duality: Theory and Applications. Kluwer Academic, Boston/ Dordrecht.

Hall, Robert E. (1988): The relation between price and marginal cost in U.S. industry. Journal of Political Economy, 96, 921-947.

Halpern, László, Körösi, Gábor (2001a): Markups in Hungarian corporate sector. Working Paper No. 411. William Davidson Institute at the University of Michigan Business School, Ann Arbor, Michigan.

Halpern, László, Körösi, Gábor (2001b): Efficiency and market share in Hungarian corporate sector. Economics of Transition 9, 559-592.

Hoekman, Bernard, Kee, Hiau Looi, Olarreaga, Marcelo (2001): Mark-ups, entry regulation and trade: does country size matter? Discussion Paper No. 2853. Centre for Economic Policy Research, London.

Hylleberg, Svend, Jørgensen, Rikke W. (1998): A note on the estimation of markup pricing in manufacturing. Working Paper No. 1998-6. Centre for Non-linear Modelling in Economics, University of Aarhus, Aarhus.

Justman, Moshe (1987): An extension of Lerner's monopoly index for markets with a disparity between long- and short-run demand elasticities. Economic Inquiry 25, 681-694.

Kee, Hiau Looi (2002): Markups, returns to scale, and productivity: a case study of Singapore's manufacturing sector. Policy Research Working Paper No. 2857. The World Bank, Washington, D.C.

Konings, Jozef, Van Cayseele, Patrick, Warzynski, Frederic (2001): The dynamics of industrial mark-ups in two small open economies: does national competition policy matter? International Journal of Industrial Organization 19, 841-859. 
Konings, Jozef, Van Cayseele, Patrick, Warzynski, Frederic (2003): The effect of privatization and international competitive pressure on firms' price-cost margins: micro evidence from emerging economies. Discussion Paper No. 3703, Centre for Economic Policy Research, London.

Linnemann, Ludger (1999): Sectoral and aggregate estimates of the cyclical behavior of markups: evidence from Germany. Weltwirtschaftliches Archiv 135, 480-500.

Morrison, Catherine J. (1992): Markups in U.S. and Japanese manufacturing: a short-run econometric analysis. Journal of Business and Economic Statistics 10, 51-63.

Norrbin, Stefan C. (1993): The relation between price and marginal cost in U.S. industry: a contradiction. Journal of Political Economy, 101, 1149-1164.

Oliveira Martins, Joaquim, Scarpetta, Stefano, Pilat, Dirk (1996): Mark-up ratios in manufacturing industries. Estimations for 14 OECD countries. Working Paper No. 162. OECD Economics Department, OECD, Paris.

Oliveira Martins, Joaquim, Scarpetta, Stefano (1999): The levels and cyclical behaviour of mark-ups across countries and market structures. Working Paper No. 213. OECD Economics Department, OECD, Paris.

Quinzii, Martine (1992): Increasing Returns and Efficiency. Oxford University Press, Oxford/ New York/Toronto/ Melbourne.

Roeger, Werner (1995): Can imperfect competition explain differences between primal and dual productivity measures? Estimates for US manufacturing. Journal of Political Economy 103, 316-330.

Roberts, Mark J., Supina, Dylan (1996): Output price, markups, and producer size. European Economic Review 40, 909-921.

Roberts, Mark J., Supina, Dylan (2000): Output price and markup dispersion in micro data: the roles of producer heterogeneity and noise. In: Baye, Michael R. (ed.): Industrial Organization. Advances in Applied Microeconomics, Vol. 9. Elsevier Science, Amsterdam/New York/ Tokyo, pp. 1-36.

Shapiro, Matthew D. (1987): Measuring market power in U.S. industry. Working Paper No. 2212. National Bureau of Economic Research, Cambridge, MA.

Weiss, Christoph R. (2000): Markups, industry structure and the business cycle. Applied Economics Letters 7, 189-191. 
Wu, Yangru, Zhang, Junxi (2000): Endogenous markups and the effects of income taxation: theory and evidence from OECD countries. Journal of Public Economics 77, 383-406. 
